УДК [911.31:625.42] (477.-25) «1919/1991»

DOI https://doi.org/10.32837/apfs.v0i32.1026

\author{
П. I. Коряга \\ ORCID ID: https://orcid.org/0000-0002-2249-3083 \\ аспірант кафедри теорії та історії культури \\ Львівського національного університету імені Івана Франка
}

\title{
КИЇВСЬКИЙ МЕТРОПОЛІТЕН ЯК ЧИННИК ФОРМУВАННЯ КУ ЛЬТУРНОГО ЛАНДШАФТУ ВЕЛИКОГО УКРАЇНСЬКОГО МІСТА В РАДЯНСЬКИЙ ПЕРІОД
}

Постановка проблеми. У сучасному світі майже $56 \%$ населення Землі, за даними звіту ООН на 2019 р. [12, с. 15], зосереджене в містах. Міста завжди були основними культурними, політичними, соціальними та науковими центрами, тож саме тут зосереджений розвиток людської цивілізації. Урбанізація стала невід'ємною частиною розвитку суспільства вже в період Античності, адже саме тоді були створені перші античні міста-держави. Саме в цей період була сформована ідея міста як основного цивілізаційного центру. В епоху Середньовіччя на мапі світу вже було в рази більше міст, але в результаті промислової революції у XIX ст. ріст урбанізації пришвидшується, уже у XX ст. сягає свого піка.

$\mathrm{y}$ процесі урбанізації, який пов'язаний насамперед із концентрацією великої кількості людей на обмеженій, але досить великій території, великого значення набуває можливість легкого частого пересування на далекі відстані. А отже, стає актуальним розвиток громадського транспорту. У першій половині XIX ст. з'являються перші зразки громадського транспорту - багатомісні візки на кінській тязі та кінні трамваї. 3 розвитком технологій, зокрема 3 появою парового двигуна й електричної енергії, уже в другій половині XIX ст. набувають поширення електричні трамваї, автобуси та потяги. Громадський транспорт першочергово допомагає вирішити поставлену проблему з переміщенням людей у різні точки в межах міста, але через високі темпи індустріалізації міста продовжують розширюватися, як у географічному плані, так і в кількості населення. У середині XIX ст. постає проблема іншого характеpy: як максимально велику кількість людей перемістити з однієї точки в іншу, причому за мінімальний період часу. Уже в 1863 р. в Лондоні запускають першу лінію метрополітену.

Поява метрополітену здійснила прорив у сфеpi громадського транспорту, на початку XX ст. метро з'явилося в майже десяти містах по всьому світу. Попри важку технологію будівництва, метрополітен чудово підходив для швидкої міської мобільності та ставав головною транспортною артерією міст. У середині XX ст. у великих містах та мегаполісах метрополітен починає відігравати важливу роль у їх розбудові, а також формуванні культурного ландшафту.
Культурний ландшафт є суспільним надбанням людини та визначається як просторове відображення еволюційно накопичених культур у певній місцевості, своєрідна проєкція культури на природний ландшафт. Місто вважається максимальною репрезентантою цього поняття, своєрідним апогеєм, адже саме тут зосереджуються більшою мірою всі надбання діяльності людини. До культурного ландшафту міст фактично належить усе, що розташоване і відбувається в ньому, зокрема: архітектура, образотворче мистецтво, музика, кінематограф, побутова культура та все інше, що створене людиною. 3 іншого боку, хоч суспільство загалом формує цей культурний ландшафт, проте також цей ландшафт впливає і на кожного із членів суспільства, формує його особистість. Звідси випливають взаємопов'язаність та циклічність цих процесів - ми формуємо культурний ландшафт, який формує нас [2].

Аналіз досліджень. Проблема взаємодії індивіда, суспільства та культурного ландшафту $€$ важливою в дослідженні цієї теми загалом, а метрополітен $є$ лише частиною цього великого механізму, хоч і досить значною. У контексті формування культурного ландшафту за допомогою мистецтва важливими для розкриття теми $€$ наукові доробки Отто Шлютера та Карла Зауера, а також російських географів Юрія Веденіна та Володимира Каганського. Варто зауважити, що сама проблема формування культурного ландшафту в радянський період не висвітлена належним чином. Це стосується й метрополітену як елементу повсякденної побутової культури мільйонів жителів великих міст. В Україні функціонують 3 метрополітени: у Києві, Харкові, Дніпрі, що були побудовані в часи активної розбудови та перебудови цих міст у період УРСР. Водночас досліджень щодо цього зовсім не багато: так, Київському метрополітену присвячені праці Григорія Головка, Миколи Коломійця, Федора Заремби, Тамари Целіковської, Костянтина Козлова, Григорія Мельничука. Вони мають більшою мірою історичний та мистецтвознавчий, а не філософсько-культурологічний характер. Зважаючи на це, є потреба у вивченні культурного ландшафту українських міст, виявленні його впливу на формування світогляду людини, яка живе в такому 
середовищі, включаючи історичні й ідеологічні контексти різних часів.

Мета статті - висвітлення формування культурного ландшафту українських міст у радянський період крізь призму феномену громадського транспорту, зокрема метрополітену.

Виклад основного матеріалу. Поняття «культурний ландшафт», за Отто Шлютером, який уводить його в науковий дискурс, відображає матеріальну єдність природних і культурних об'єктів, доступних сприйняттю людини; він має визначальний вплив на формування людського світогляду [5]. Важливим внеском у розвиток концепції поняття культурного ландшафту також було дослідження американського географа Карла Зауера, який у книзі «Морфологія ландшафту» визначив його як просторове відображення еволюційно накопичених культур у певній місцевості, своєрідну проєкцію культури на природний ландшафт. У центрі уваги, згідно з концепцією К. Зауера, мають перебувати «нашарування» способів життя, які людина залишає в ландшафті. Культура трактується як цілісність людського досвіду, основна сила, що формує рукотворний образ земної поверхні [10].

Варто зазначити, що в дослідженні культурного ландшафту варто брати до уваги два аспекти. Перший стосується феномену урбанізації та феномену міста як такого, зокрема створення перших міст у період Античності. Другий - наявність громадського транспорту, зокрема метрополітену, появу якого пов'язують із промисловою революцією та швидкою урбанізацією територій.

Згідно 3 «Універсальним словникоменциклопедією», термін урбанізація (від лат. urbanus - міський) уживається на позначення зростання значущості міст у розвитку суспільства, яке супроводжується ростом і розвитком міських поселень, зростанням кількості міського населення та поширенням міського способу життя в певному регіоні чи країні [11]. Фактично, урбанізація була та залишається взаємопов' язаною з розвитком людської цивілізації, взаємопов'язаність цих процесів можна простежити в історичному розвитку людства.

3 розвитком міст у XIX ст. постає проблема масової маятникової міграції людей з точки А в точку Б, як у межах одного міста, так із сусідніх менших населених пунктів. Це стало першопричиною появи сучасного для нас поняття - «громадський транспорт». Першою мережею громадського транспорту, яка з'явилася у французькому місті Нанті в 1826 р., уважається мережа омнібусів - це був багатомісний візок на кінській тязі, який уважають попередником сучасного автобуса. Уже в 1886 р. в Лондоні з'являється перший паровий автобус. Паралельно з першими автобусами з'являються також трамваї на кінній тязі. Перший такий з' являється в 1828 р. в місті Балтиморі, що у штаті Меріленд (США). У 1881 р. $з$ поширенням у всьому світі електрики було створено першу пасажирську електричну трамвайну лінію між Берліном і Ліхтерфельде. Київ став першим українським містом (а також першим містом у Російській імперіï), у якому в 1892 р. з'явився трамвай.

3 розвитком промисловості, громадського транспорту міста збільшують кількість населення та свої площі, отже, виникає проблема одночасного переміщення великої кількості людей. Її вирішують різними методами, зокрема збільшенням кількості одиниць громадського транспорту та його видів. Так, паралельно із трамваями й автобусами в 1863 р. в Лондоні запускають першу у світі лінію метрополітену. Будівництво метрополітену дуже складне та дороге, але метро дієво вирішує транспортні проблеми, є швидким у перевезенні великої кількості пасажирів. Через вищезгадані чинники метрополітен і набуває такої популярності у великих містах, уже в кінці XIX на початку XX ст. лінії метро отримали такі міста, як Нью-Йорк, Париж, Будапешт, Глазго, Берлін та Гамбург. Невід'ємною частиною метрополітену стають довгі тунелі, вагони потягу та станції. У 1935 р. перший метрополітен Радянського Союзу з' являється в Москві, а в 1960 р. - у Києві, перший в Україні [1].

У часи побудови першої лінії московського метрополітену в Радянському Союзі ще панував тоді популярний у всьому світі модерністський стиль. Архітектура на той час, попри намагання партії впорядкувати іiї під свої вподобання, залишається досить прогресивною. Однозначно, перша у СРСР лінія метро була гордістю технічного прогресу держави та партії, тому оформленню станцій метрополітену приділяли особливу увагу. Перші 13 станцій лінії метро від «Сокольнікі» до «Парк культури» відкрили навесні 1935 р. Станції були оформлені в популярних тоді стилях - конструктивізму, авангардизму й арт-деко, з використанням найкращих та найрізноманітніших матеріалів 3 усього Радянського Союзу. Так тривало до поширення в 1937 р. так званого нового стилю - «сталінського неокласицизму», одним з авторів якого вважають російського архітектора Івана Жолтовського. І. Жолтовський ще в 1934 р. побудував житловий будинок у Москві у стилі неокласицизму, згодом цей стиль активно поширюється серед архітекторів. Уже у другій половині 1930-х рр. за негласним наказом Йосифа Сталіна неокласицизм стає основним архітектурним стилем у всьому Радянському Союзі. Проблема конструктивізму, авангардизму й арт-деко була в тому, що ці напрями в архітектурі мали відверте буржуазне походження та стрімко розвивалися в усьому світі, зокрема й капіталістичному. Саме для протиставлення цим провідним мистецьким напрямам i запроваджується сталінський неокласицизм, який мав би представляти велич Радянського 
Союзу на мистецькій мапі, з одного боку, а з іншого - формувати в пересічної людини відчуття величі своєї країни та захвату від неї. Для такої тоталітарної держави, як Радянський Союз, архітектура мала бути засобом пропаганди державної влади та режиму, а зробити це на основі так званих буржуазних стилів не вдавалося, оскільки радянська ідеологія грунтувалася на міфологемі «свій - чужий» та сприймала весь інший світ як ворожий. Натомість сталінський неокласицизм, який є наступником класицизму і по суті стилем великих імперій, якраз добре підходив для пропаганди величі держави, тому запровадження такого стилю як єдиного в державі, масштабна забудова міст такою архітектурою допомогли Комуністичній партії прирівняти Радянську державу до Давньоримської імперії, де була різниця тільки в тому, що всі ці величні споруди побудовані не для аристократів та вельмож, а для звичайних громадян.

Усі процеси зі зміною архітектурного стилю в державі дуже добре можна помітити на станціях другої черги московського метрополітену від «Смоленської» до «Київської», які були відкриті в 1937 р., та на станціях, які побудували в часи Другої світової війни - «Площа Революції», «Маяковська», «Новокузнєцка» й інші, що були збудовані після війни. Оформленням цих станцій займалися видатні архітектори, а для оздоблення використовували дорогі матеріали, ліпнину, кольорові метали та найрізноманітніші види каменю. Станції цього періоду більше нагадують вестибюлі чи зали вишуканих королівських палаців, аніж станції громадського транспорту. Саме за часів правління Йосифа Сталіна у СРСР архітектура й усе мистецтво набувають найвищої точки у пропагуванні ідей панівної партії. Радянська символіка, зображення звичайних людей, які працюють для створення соціалістичного майбутнього, - усі ці настрої були відбиті майже в усіх мистецьких творах тих часів [7].

Після смерті Йосифа Сталіна в 1953 р. до влади приходить Микита Хрущов, починається так звана «хрущовська відлига», а в1955 році у зв’ язку з постановою ЦК КПРС і РНК СРСР «Про усунення надмірностей у проєктуванні і будівництві» [9] такий стиль, як «сталінський неокласицизм», припиняє існування. Архітектурний стиль, з одного боку, втрачає необхідність бути підсиленням культу вождя, а з іншого - $є$ надто дорогим навіть для такої держави, як СРСР, у якій після Другої світової війни була критична ситуація з відбудовою міст та житлом для громадян. Основним пріоритетом партії стала не велична і дорога архітектура, а проста та дешева забудова, яка могла в найкоротші терміни забезпечити необхідний попит. Так, у другій половині 1950-х рр. у Радянському Союзі з'являється перше типове та масове будівництво - так звані «хрущовки» .
Варто зазначити, що саме в часи УРСР було закладено 3 метрополітени, які існують дотепер, - це лінії метро в Києві, Харкові та Дніпрі. Спроби побудови метрополітену можна простежити і в інших містах України, були розроблені проєкти для Львова й Одеси, проте ці плани так і не були втілені.

Історія українського метрополітену бере свій початок у 1944 р., після затвердження проєкту підземки Києва Комуністичною партією УРСР, а саме будівництво розпочалось у 1949 р. Через специфічний рельєф Києва - пливуни, що розмивали підземні породи, - під час будівництва тунелів виникали постійні труднощі. У другій половині 1949 р. було збудовано перші шахти, а через два роки, у 1951 р. відбулося об'єднання тунелів станцій «Хрещатик» i «Арсенальна». Станція «Арсенальна» і дотепер уважається найглибшою станцією метрополітену у світі (глибина - 105,5 м). Будівництво та відкриття метрополітену в Києві було важливою подією та пропагувалося на загальнодержавному рівні, тому до оформлення перших станцій метро тут поставилися не менш відповідально, ніж до оформлення станцій метрополітену в Москві. Уже на початку 1958 р. оголосили конкурс на найкращі проєкти для станцій, а також створили спеціальну комісію за участі архітекторів, інженерів, митців та представників державних органів для розгляду конкурсних робіт. Усього на цей конкурс подали 80 проєктів, 5 із яких було визначено переможцями та втілено в будівництві й оформленні станцій Святошино-Броварської лінії - «Вокзальна», «Університет», «Хрещатик», «Арсенальна» та «Дніпро» [4]. Повністю облицьована білим мармуром, станція «Вокзальна», за задумом архітекторів, слугувала своєрідним знайомством з історією України, адже на бокових стінах станції розміщені медальйони авторства художника Олександра Мизіна із зображенням історичних подій, вигідних на той час для партії, які поєднували історію України та Росії як «дружніх» народів. Станція «Університет» - це чудовий приклад поєднання архітектури та декоративного мистецтва. Сама станція облицьована коричневим мармуром із гіпсовою ліпниною, а в кожному пілоні розміщені бюсти 8 відомих українських та російських письменників. Станція «Хрещатик» - центральна станція столиці, тому в оформленні архітектори звернулися до українського народного мистецтва, зобразивши на вставках із майоліки соняхи та кукурудзу. Облицювання станції «Арсенальна» досить просте та поєднує в собі білий і рожевий Новоселецький мармур, алюмінієві елементи, що імітують бронзу. Першою відкритою станцією метро в Києві стала станція «Дніпро», де основною прикрасою став вид на Дніпро та комплекс скульптур «Мир» та «Праця», а до 1965 р. ця станція була кінцевою Червоної лінії [4].

Уже 6 листопада 1960 р. із грандіозним розмахом була відкрита перша лінія метрополітену Києва. Саме після відкриття першої лінії метрополітену 
та будівництва нових станцій Київ почав змінювати свій вигляд та ландшафт. Після відкриття першої черги, упродовж наступних 11 років було відкрито 9 станцій, серед яких «Політехнічний інститут», «Шулявська», «Гідропарк», «Лівобережна», «Дарниця» й інші. У 1971 р. почалося будівництво другої гілки метро - Оболонсько-Теремківської лінії. Щоб зекономити, будівництво вирішили вести відкритим способом, у результаті якого було зруйновано будівлі в історичному ареалі Києва, а під час будівництва було знайдено багато артефактів княжого періоду. У 1976 р. було запущено другу гілку метро із трьома станціями - «Червона площа» (нині «Контрактова площа»), «Поштова площа» та «Жовтневої революції (нині - «Майдан Незалежності»). У 1981 р. почалося будівництво третьої гілки Сирецько-Печерської лінії. Через політичну й економічну нестабільність СРСР у 80-х рр. будівництво третьої гілки затягується, лише в 1989 р. вдається відкрити 3 станції- «Золоті ворота», «Палац спорту» та «Кловська». До речі, станцію «Золоті ворота», яка оформлена в давньоруському стилі, з мозаїками зі смальти та тематичними світильниками, уважають однією з найкрасивіших у світі [6].

Загалом Київський метрополітен за часи свого існування став особливим архітектурним ансамблем та історичною пам'яткою Києва. Перша черга станцій метрополітену вражає своїм багатим оздобленням та має всі риси архітектури сталінського неокласицизму, натомість друга черга, хоч і більш скромна в оздобленні, усе ж є гарним прикладом модернізму. Понад 20 нових станцій, які були побудовані в часи незалежності, є прикладами сучасних архітектурних течій, зокрема й хай-теку. Нині активно ведеться продовження третьої гілки до мікрорайону Виноградар, проєктується 4 лінія метро, яка має з'єднати район Троєщину із центом міста [8].

Висновки. Поява метрополітену у великих українських містах, зокрема в Києві, була цілком логічною, адже в часи Радянського Союзу будівництво метрополітену у столиці однієї з республік була знаковою подією та пропагувалося на загальнодержавному рівні. У Комуністичній партії добре розуміли той факт, що метрополітен є не тільки громадським транспортом, а інструментом пропаганди та майбутньою частиною як культурного ландшафту міста, так і повсякдення громадян. Кожного дня, перебуваючи певний час у метрополітені, радянська людина вбирала в себе всі меседжі, які пропагував цей простір. Саме тому в оздобленні станцій часто використовувались такі теми, як: непохитна дружба російського й українського народів, віра у світле соціалістичне майбутне, заклики до праці, інші пропагандистські гасла. Усе це в комплексі з активним формуванням «правильної» для партії забудови міста та створення «правильного» мистецтва, яке розвива- лося в місті, формувало ідеологічно зручний для держави культурний ландшафт, який поширював визначені ідеї та виховував радянську людину.

Метрополітен протягом усього часу свого існування і справді змінив ландшафт Києва та став його невід'ємним елементом. Його поява докорінно змінила стиль життя мешканців міста, а його активне функціонування та використання і далі продовжує впливати на світогляд людей, які ним користуються. Здебільшого це відбувається як через збереження наявних форм і елементів оздоблення, так і через удосконалення цього виду міського транспорту, розвиток нових міських просторів навколо його станцій.

\section{Jimepamypa}

1. Алфьоров М. Урбанізаційні процеси в Україні в 1945-1991 рр. : монографія. Донецьк, 2012. 552 с.

2. Веденин Ю. Искусство как один из факторов формирования культурного ландшафта. Известия Академии наук Союза Советских Социалистических Республик. Серия «География». 1988. № 1. С. 17-24.

3. Головко Г., Коломиец Н. Киевский метрополитен. Киев, 1963. 42 с.

4. Заремба Ф., Целиковская Т. Киевский метрополитен. Киев, 1976.96 с.

5. Каганский В. Ландшафт и культура. Общественные науки и современность. 1997. № 1. С. 134-145.

6. Козлов К. Київський метрополітен. Київ, 2011. 256 с.

7. Костина О. Архитектура московского метро 1935-1980-е гг. Москва, 2019. 208 с.

8. Мельничук Г. 50 років Київському метрополітену. Київ, 2010. 210 с.

9. Об устранении излишеств в проектировании и строительстве : постановление Центрального Комитета КПСС и Совета Министров СССР от 4 ноября 1955 г. № 1871. URL: https://web.archive. org/web/20140716132943/http://sovarch.ru/ postanovlenie55/ (дата звернення: 18.11.2021).

10. Стрелецкий В. Культурно-ландшафтные исследования в Германии: традиции и современность. Культурный ландшафт: теоретические и региональные исследования. 2003. С. 42-54.

11. Універсальний словник-енциклопедія (УСЕ) / ред. рада : М. Попович та ін. Київ, 1999. 1551 с.

12. Review and appraisal of the Programme of Action of the International Conference on Population and Development and its contribution to the follow-up and review of the 2030 Agenda for Sustainable Development : Report of the Secretary-General by 18.01.2019. URL: https://documents-dds-ny.un.org/doc/UNDOC/GEN/ N19/015/35/PDF/N1901535.pdf?OpenElement (дата звернення: 18.11.2021).

\section{Анотація}

Коряга П. І. Київський метрополітен як чинник формування культурного ландшафту великого українського міста в радянський період. - Стаття.

У статті проаналізовано поняття культурного ландшафту, який відображає матеріальну єдність природних і культурних об'єктів та має визначальний вплив на формування людського світогляду. Визначено особливості формування культурного ландшафту в радянський період, його вплив на становлення радянської людини. Окреслено поняття урбанізації як характерної 
риси розвитку людської цивілізації; простежено історичний розвиток урбаністичних аспектів генези людства, установлено прямий зв'язок урбанізації та міста 3 поняттям культурного ландшафту. Вивчено феномен міста як репрезентанта культурного ландшафту, з огляду на те, що тут зосереджуються більшість надбань діяльності людини. До культурного ландшафту міст фактично належить усе, що розташоване і відбувається в ньому, зокрема: архітектура, образотворче мистецтво, музика, кінематограф, побутова культура та все інше, що створене людиною. 3 цього погляду розглянуто історичний розвиток громадського транспорту, починаючи з розгляду перших його видів у XIX столітті - кінних автобусів та трамваїв, запуску першої лінії метрополітену в Лондоні до появи ліній метрополітену в Радянському Союзі. Особливий акцент у дослідженні зроблено на історичному аналізі будівництва станцій Київського метрополітену. Виявлено характерні риси архітектурного, мистецького оформлення станцій, з'ясовано, які ідеологічні меседжі пропаганди були закладені в їхньому оздобленні, який це мало вплив на культурний ландшафт міста. Досліджено особливості мистецтва в Радянському Союзі, його безпосередній зв'язок із радянською ідеологією, зокрема і засоби, які пропаганда застосовувала за допомогою мистецтва. 3'ясовано сутнісні відмінності між архітектурними стилями (конструктивізм, арт-деко, авангардизм, сталінський неокласицизм) крізь призму ідеологічної складової частини Комуністичної партії Радянського Союзу.

Ключові слова: культурний ландшафт, метрополітен, місто, архітектура, пропаганда, радянська людина.

\section{Summary}

Koryaha P. I. Kyiv underground as a factor of formation of the cultural landscape of big Ukrainian city during the Soviet Union period. - Article.

In this article is analyzed the cultural landscape as a phenomenon, which reflects the material unity of natural and cultural objects and has a decisive influence on the formation of human worldview. The features of formation of the cultural landscape in the Soviet period and its influence on the soviet character is also defined. The phenomenon of urbanization is described, as a lead point of the human civilization development; the historical development of urbanism as a part of human development is followed as well as the straight connection between urbanism and cultural landscape is established. The phenomenon of the city as a representative of the cultural landscape is considered, as here the most of human activity achievements is centered. Cultural landscape mostly owns everything that happens there, particularly architecture, art, music, cinematography, everyday culture, and everything else, created by a human. In this case considered the historical development of the underground as the public transport is described; starting from the presence of the first known types of public transport in XIX century - horse buses and trams, then moving to the first underground line in London, and then - to the moment of the first underground system in the Soviet Union appearance. The special accent is made on features of construction and decoration of stations of Kyiv underground. In particular, the main features of Kyiv underground show up in the unique style of an architectural, artistic decorations of each station, the ideological messages of propaganda that were laid in the decoration of the stations and what influence it has had on the city's cultural landscape. The features of art in Soviet Union are discovered, as well as its straight connection to the Soviet ideology, amongst it, means that propaganda used through the art. The main differences between architectural styles (constructivism, art-deco, avantgarde, Stalin neoclassicism) are discovered through the prism of ideological consistence of CPSU.

Key words: cultural landscape, underground, city, architecture, propaganda, soviet person. 